\title{
A new epithelial cell line, SSK from kidney of striped snakehead Channa striatus (Bloch 1793)
}

\author{
D. K. CHAUDHARY, N. SOOD, D. K. VERMA, T. R. SWAMINATHAN*, B. KUSHWAHA, \\ R. ABIDI AND P. K. PRADHAN \\ ICAR-National Bureau of Fish Genetic Resources, Canal Ring Road, P. O. Dilkusha, Lucknow - 226002 \\ Uttar Pradesh, India \\ *Peninsular and Marine Fish Genetic Resources Centre, ICAR-National Bureau of Fish Genetic Resources \\ CMFRI Campus, PB No. 1603, Kochi - 682 018, Kerala, India \\ e-mail:sood_neeraj@rediffmail.com
}

\begin{abstract}
A cell line was established from striped snakehead Channa striatus kidney. The cell line, named as SSK, has been passaged for over 62 times. Growth studies at different temperatures and foetal bovine serum (FBS) concentrations revealed that SSK cells show optimum growth at $28^{\circ} \mathrm{C}$ in L-15 medium containing $20 \%$ FBS. The chromosome number of SSK cells was $2 \mathrm{n}=40$. Partial sequencing of mitochondrial cytochrome oxidase 1 gene of the cells confirmed that the cell line originated from $C$. striatus. The SSK cells were primarily epithelial, as determined using immunophenotyping. The cells from SSK cell line were transfected with phrGFP II-N mammalian expression vector. The SSK cell line was stored in liquid nitrogen $\left(-196^{\circ} \mathrm{C}\right)$ at different passages and was successfully revived after four months of storage. The cell line could be successfully employed for cytotoxicity studies, as revealed by neutral red assay. The cell line can be a valuable surrogate to the whole fish studies.
\end{abstract}

Keywords: Cell line, Channa striatus, Karyotype, Kidney

\section{Introduction}

The striped snakehead Channa striatus from the family Channidae, are highly valued food fish in India (Talwar and Jhingran, 1992). The fish inhabits rivers, ponds, canals, swamps, lakes and rice fields (Hossain et al., 2008). It is considered as a potential species for aquaculture (NBFGR, 2011) owing to several desirable traits, namely good price and capability to withstand adverse environmental conditions due to air breathing ability and hardiness (Samantaray and Mohanty, 1997). Moreover, the flesh of C. striatus has high nutritive value besides other medicinal value (Courtenay and Williams, 2004). However, overexploitation as well as several man-made factors has resulted in decline in the native stock (Hossain et al., 2008). Aquaculture of this species can serve multiple purposes including conservation and restocking programs as well as species diversification in freshwater aquaculture. However, various diseases are bound to occur during fish culture. Therefore, development of in vitro test systems like cell lines and determining their optimal growth requirements are important (Grunow et al., 2011).

Cell lines are important tools for studies on animal physiology, virology and toxicology which can provide highly reproducible results (Buonocore et al., 2011). As per Lakra et al. (2011), approximately 283 cell lines have been developed from finfish. Furthermore, several workers established cell lines from C. striatus, namely SSN-1 (Frerichs et al., 1991); CSK and CSG (Abdul Majeed et al., 2013, 2014) and CST (Sood et al., 2015). In the present study, we describe the establishment a cell line from the kidney of C. striatus.

\section{Materials and methods}

Primary cell culture and maintenance

A healthy snakehead, C. striatus weighing $65 \mathrm{~g}$ was euthanised with MS222 (Sigma-Aldrich, Missouri, United States of America), swabbed with $70 \%$ ethanol and its kidneys were aseptically dissected. The kidney tissue was cleaned four times in phosphate buffered saline (PBS) with antibiotic-antimycotic solution (2X) (Invitrogen, Paisley, UK) and shifted to a fresh petridish containing PBS with antibiotic-antimycotic solution. The tissue was cut into approximately $1 \mathrm{~mm}^{3}$ explants using sterile scissors, which were transferred to a $25 \mathrm{~cm}^{2}$ cell culture flask. The PBS was removed with help of micropipette and $250 \mu \mathrm{l}$ of foetal bovine serum (FBS) was added. The flask was incubated at $28^{\circ} \mathrm{C}$ overnight to allow attachment of explants. Subsequently, $5 \mathrm{ml}$ of L-15 medium with $20 \%$ FBS and $1 \mathrm{x}$ conc. of antibiotic-antimycotic solution was added to the flask. The 
flask was again incubated at $28^{\circ} \mathrm{C}$ and about $50 \%$ of the medium was replenished every $4^{\text {th }}$ day with fresh medium. The medium was decanted, after the cells reached $90 \%$ confluence, followed by two washings with PBS. Thereafter, the cells were harvested using trypsin-EDTA solution (Invitrogen) and passaged at a split ratio of 1:2. The concentration of FBS in medium was gradually reduced from 20 to $10 \%$ between $10^{\text {th }}$ and $20^{\text {th }}$ subculture. After every $10^{\text {th }}$ passage, $1 \times 10^{6}$ cells were resuspended in $1 \mathrm{ml}$ of cryopreservation medium (FBS with $10 \%$ dimethyl sulphoxide) and transferred to a cryovial, which was stored overnight at $-80^{\circ} \mathrm{C}$ and then transferred to liquid nitrogen $\left(\mathrm{LN}_{2}\right)$. For revival, the cryovial was thawed quickly at $37^{\circ} \mathrm{C}$ and its contents were transferred drop-wise to a tube containing $10 \mathrm{ml}$ of $\mathrm{L}-15$ medium. The tube was centrifuged at $200 \mathrm{~g}$ for $5 \mathrm{~min}$ at room temperature, medium was discarded and the pellet was resuspended in fresh medium. The viability of the stored cells after thawing was calculated by trypan blue staining using a haemocytometer. The cells were subsequently seeded in $25 \mathrm{~cm}^{2}$ flask

Growth studies of cells

The SSK cells were cultured at various temperatures and FBS concentrations to determine the optimum temperature and serum concentration. At $32^{\text {nd }}$ passage, SSK cells ( $1 \times 10^{5}$ cells ml ${ }^{-1}$ of L-15 medium with $20 \%$ FBS) were seeded in $25 \mathrm{~cm}^{2}$ cell culture flasks, which were subsequently incubated at $28^{\circ} \mathrm{C}$ overnight. Thereafter, the cells were incubated at various temperatures viz. $24,28,32$ and $37^{\circ} \mathrm{C}$. The effect of temperature on SSK cells was studied for 4 days. Daily, three flasks at each temperature were harvested to calculate the cell number. A similar study was conducted with $33^{\text {rd }}$ passage SSK cells at $28^{\circ} \mathrm{C}$ to know the effect of various FBS concentrations (5, 10, 15 and 20\%).

\section{Plating efficiency}

To know the plating efficiency of SSK cells, $56^{\text {th }}$ passage cells were seeded at cell densities of 100, 500 and 1,000 cells per flask $\left(25 \mathrm{~cm}^{2}\right)$ and cultured in L-15 medium with $10 \% \mathrm{FBS}$ at $28^{\circ} \mathrm{C}$. About half volume of the medium was replaced with new medium after every 3 days. After 10 days, cells were washed with PBS after decanting the medium. Thereafter, methanol was added to the flasks to fix the cells which were subsequently stained using crystal violet. The flasks were observed microscopically for counting the individual cell colonies. The plating efficiency was calculated following Freshney (2005) as: PE (\%) = number of cell colonies/number of cells seeded X 100.

\section{Chromosomal analysis}

The karyotype was prepared from $60^{\text {th }}$ passage cells following Freshney (2005). Briefly, the SSK cells at 75-80\% confluency were incubated for $2 \mathrm{~h}$ with colchicine solution (Invitrogen) at a final concentration of $0.2 \mu \mathrm{g} \mathrm{ml}^{-1}$. Following gentle pipetting, the detached cells were collected by centrifugation at $4^{\circ} \mathrm{C}$ and resuspended in hypotonic solution of $0.56 \% \mathrm{KCl}$. The cells were fixed with $1: 3$ acetic acid : methanol solution. After $10 \mathrm{~min}$, the cells were suspended again in fresh fixative and centrifuged. The cells were finally suspended in $0.5 \mathrm{ml}$ of fixative. Smears were prepared from cell suspension by drop-splash method, air dried and stained with Giemsa solution (5\%). Chromosome counting was carried out for 100 metaphase spreads under a light microscope.

\section{PCR for confirmation of origin of cell line}

To confirm the origin of SSK cell line, DNA was extracted at $58^{\text {th }}$ passage and muscle tissue of $C$. striatus. A fragment of cytochrome oxidase I (COI) gene was amplified as per Ward et al. (2005). The cycling conditions included denaturation at $95^{\circ} \mathrm{C}$ for $5 \mathrm{~min} ; 30$ cycles of $95^{\circ} \mathrm{C}(45 \mathrm{~s}), 50^{\circ} \mathrm{C}$ $(30 \mathrm{~s}), 72^{\circ} \mathrm{C}(45 \mathrm{~s})$; and final extension at $72^{\circ} \mathrm{C}$ for $5 \mathrm{~min}$. The PCR products were sequenced using forward and reverse primers in Applied Biosystems AB 3730 XL. The sequences of PCR fragments were aligned against known sequences from NCBI database using the Basic Local Alignment Search Tool (BLAST).

\section{Gene transfection}

The SSK cells were grown in a 6 -well plate $\left(10^{5}\right.$ cells per well). Following attachment, the cells were transfected using $2 \mu \mathrm{g}$ of phrGFP II-N vector (Stratagene, LaJolla, CA) using SatisFection reagent. The plate was incubated in dark at $28^{\circ} \mathrm{C}$. After $48 \mathrm{~h}$, the cells were observed for fluorescence under fluorescence microscope for expression of GFP (Qin et al., 2006).

\section{Immunophenotyping}

SSK cells, grown on cover slips, were fixed with methanol at $-20^{\circ} \mathrm{C}$. The cover slips were incubated with PBS containing $1 \%$ BSA at room temp (RT) for $1 \mathrm{~h}$. The cover slips were incubated at RT with primary antibodies i.e. clone AE1/AE3 antibodies (Invitrogen), mouse anti-cytokeratin (pan), or mouse anti-vimentin antibodies (Invitrogen) for 1h. After washing, cells were again incubated for $1 \mathrm{~h}$ with anti-mouse antibody labeled with FITC (1:50 in PBS) and cover slips were washed and mounted with buffered glycerol. Control cover slips were treated as described above, except that blocking buffer was used in place of primary antibody. Finally, the cover slips were observed for fluorescence under a microscope.

\section{Neutral red uptake assay}

Neutral red uptake assay was carried out following Repetto et al. (2008) for cytotoxicity studies using SSK cells that were exposed to various concentrations of mercuric chloride. Briefly, a 96-well plate was seeded with $1 \times 10^{4} \mathrm{SSK}$ 
cells per well and incubated overnight at $28^{\circ} \mathrm{C}$. Then, the culture medium was replaced with $100 \mu \mathrm{l}$ of L-15, containing various concentrations of mercuric chloride (SRL, Mumbai, India) $\left(1.96\right.$ to $\left.500 \mu \mathrm{g} \mathrm{ml}^{-1}\right)$. All the above concentrations were used in triplicate. However, in control wells, $100 \mu \mathrm{l}$ of L-15 medium without mercuric chloride was added. After 24 $\mathrm{h}$, the cells were washed and neutral red solution $(40 \mu \mathrm{g}$ per $\mathrm{ml}$ of growth medium) was added and incubated at $28^{\circ} \mathrm{C}$ for $2 \mathrm{~h}$. Then the neutral red solution was decanted. This was followed by washing of wells with $150 \mu \mathrm{l}$ of PBS twice and fixation by addition of $5 \%$ glutaraldehyde. Subsequently, neutral red was removed by adding $150 \mu \mathrm{l}$ of neutral red destaining solution to each well by shaking for $10 \mathrm{~min}$. Finally, the optical density (OD) of each well was recorded at $540 \mathrm{~nm}$ (Tecan, Austria).

\section{Results}

\section{Cell culture}

Most of the explants adhered to the flask surface and radiation of the cells was observed by $24 \mathrm{~h}$. These cells grew to form a monolayer by 18 days. After 25 passages, the cells could be passaged at a ratio of 1:3 every 5-6 days. This cell line has been designated as striped snakehead kidney (SSK) cell line. The SSK cells were stored for 4 months in liquid nitrogen and showed over $80 \%$ viability after revival. The morphology of cells did not show any alteration following freezing and thawing. Presently, the cells have been passaged for more than 62 passages during 1 year (Fig. 1).

\section{Growth studies of cells}

Variation in growth rate of SSK cells was observed at various incubation temperatures which grew moderately at 24 and $32^{\circ} \mathrm{C}$, whereas, maximum cell growth was observed at $28^{\circ} \mathrm{C}$ (Fig. 2a). At $37^{\circ} \mathrm{C}$, the SSK cells showed vacuolation followed by rounding and detachment by 4 days. Similarly, when the FBS concentration in the medium was increased from 5 to $20 \%$ at $28^{\circ} \mathrm{C}$, the growth rate of SSK cells also increased (Fig. 2b). There was moderate growth of cells at 10 and $15 \%$ FBS though maximum growth was noted at $20 \%$ FBS

\section{Plating efficiency}

Plating efficiency of SSK cell line was found to be $3.9 \pm 1.61,16.3 \pm 2.24$ and $19.2 \pm 1.38$ at seeding concentrations of 100,500 and 1000 cells flask $^{-1}$ respectively.

\section{Chromosomal analysis}

The number of chromosomes of SSK cells at passage 60 , counted from 100 metaphase spreads varied from 30

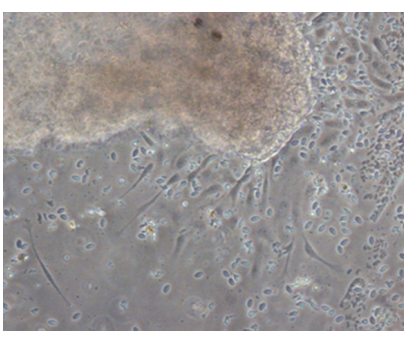

(a)

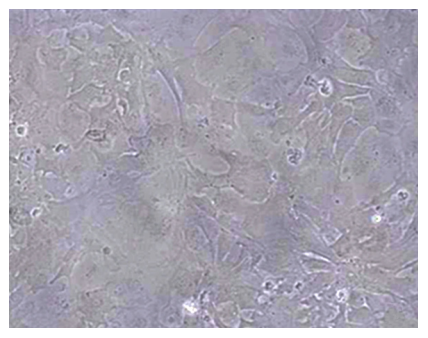

(b)

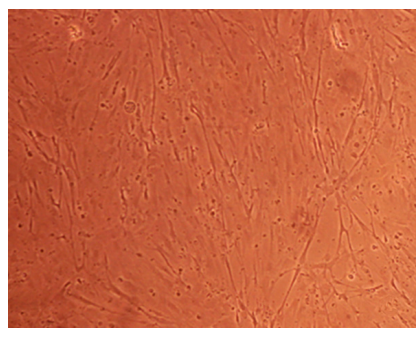

(c)

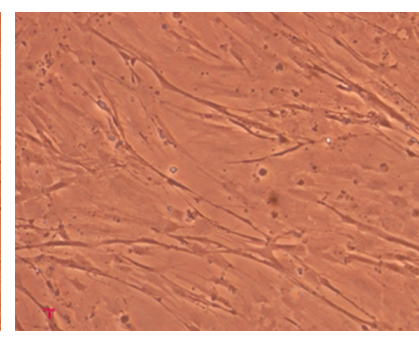

(d)

Fig. 1. Photomicrographs of SSK cells of Channa striatus (10x objectives) (a) Kidney tissue with radiation of cells; (b) Dividing cells observed after $3^{\text {rd }}$ passage; (c) SSK cells at $19^{\text {th }}$ passage and (d) SSk cells at $62^{\text {nd }}$ passage

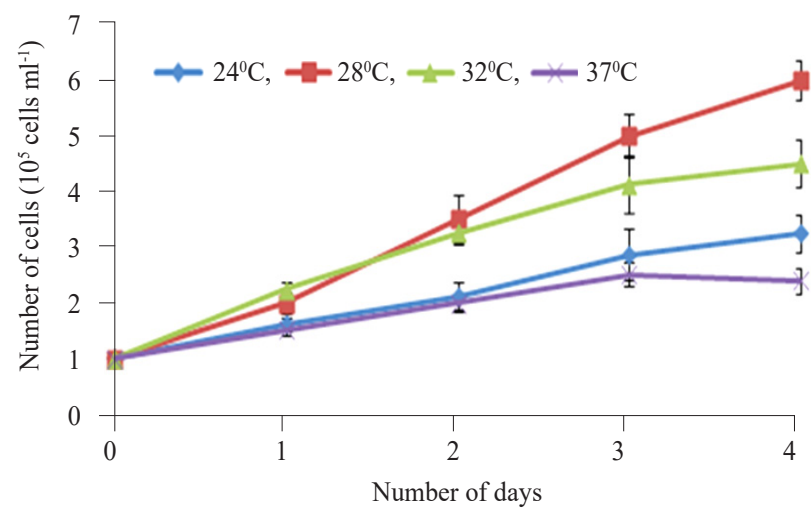

(a)

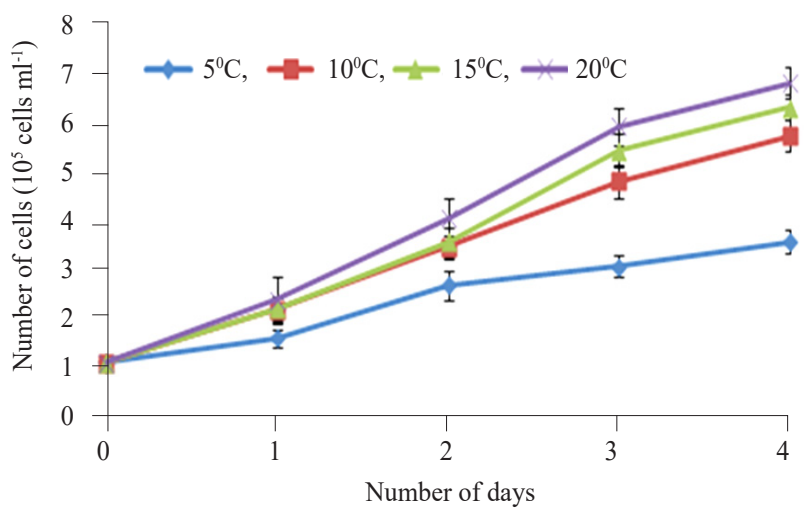

(b)

Fig. 2. (a): Growth response of SSK cells at various temperatures at $32^{\text {nd }}$ passage; (b): various concentrations of foetal bovine serum at $33^{\text {rd }}$ passage 
to 51 . However, $64 \%$ chromosome spreads had a modal chromosome number of 40. Furthermore, karyotype morphology of the spreads with diploid number was found to be normal (Fig. 3).

\section{Confirmation of origin of cell line}

Amplification of mitochondrial COI gene from SSK cells and $C$. striatus muscle tissue yielded 700 bp products (Fig. 4). Sequencing of these PCR products revealed 100\%

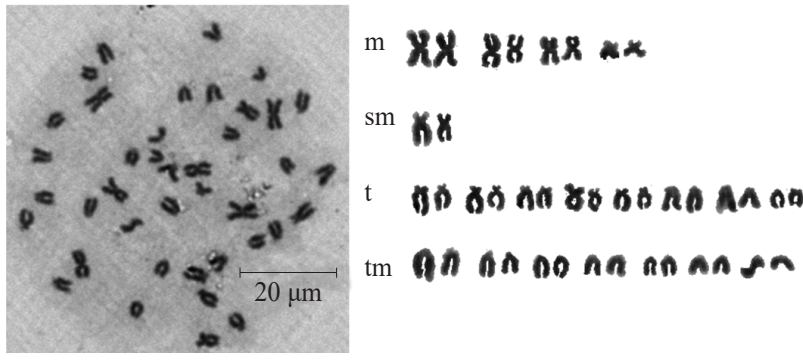

Fig. 3. Chromosomal analysis of SSK cells; A normal metaphase spread from SSK cells at passage 60 revealed 40 chromosomes $(2 n=8 m+2 s m+16 s t+14 t)$

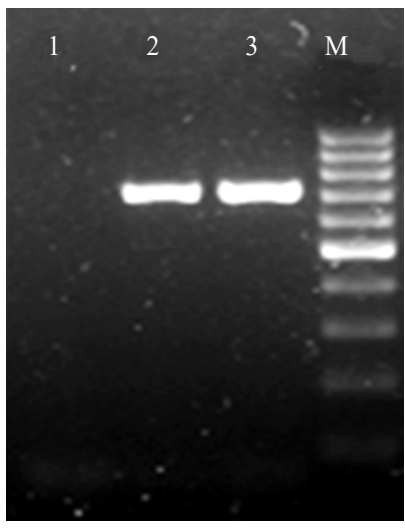

Fig. 4. PCR amplification COI gene of Channa striatus, using universal primers

Lane 1 - Negative control, Lane 2 - SSK cells, Lane 3 - C. striatus muscle, Lane M - 100 bp DNA ladder (Fermentas)

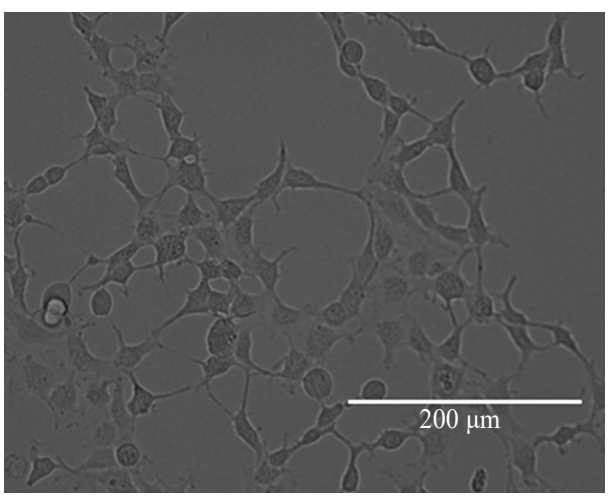

(a) sequence identity between the COI gene from SSK cells and $C$. striatus muscle and $99 \%$ similarity with C. striatus mitochondrial COI gene sequences in the GenBank database. The sequence of COI gene has been submitted to NCBI GenBank (Accession no. KT347602).

\section{Transfection}

The phrGFP II-N vector transfected SSK cells (Fig. 5), exhibited strong green fluorescence signals after $48 \mathrm{~h}$ of transfection.

\section{Immunophenotyping}

The SSK cells incubated with mouse anti-cytokeratin antibodies exhibited green fluorescence (Fig. 6), whereas, no fluorescence signals was observed in SSK cells incubated with antivimentin antibodies or in SSK cells incubated with $1 \%$ BSA.

\section{Cytotoxicity assay}

Following incubation of SSK cells with mercuric chloride at increasing concentration, there was a decrease in O.D. which indicated a decrease in neutral red uptake (Fig. 7).

\section{Discussion}

In this study, the explant method was used to establish a cell line from kidney of striped snakehead Channa striatus,

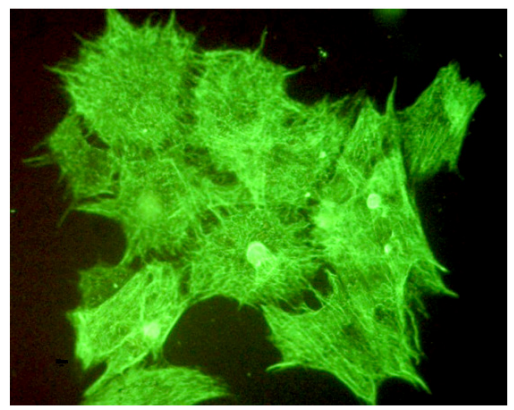

Fig. 6. Photomicrograph of SSK cells with fluorescence following incubation with anti-cytokeratin antibodies

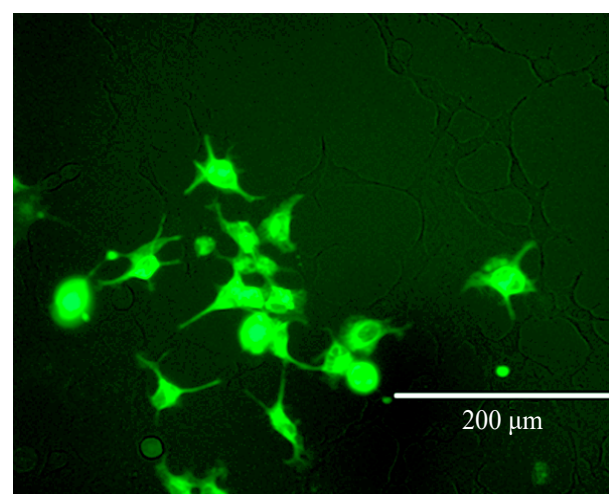

(b)

Fig. 5. The SSK cells transfected with phrGFP II-N vector expressing GFP gene at $48 \mathrm{~h}$ with passage 44 cells 


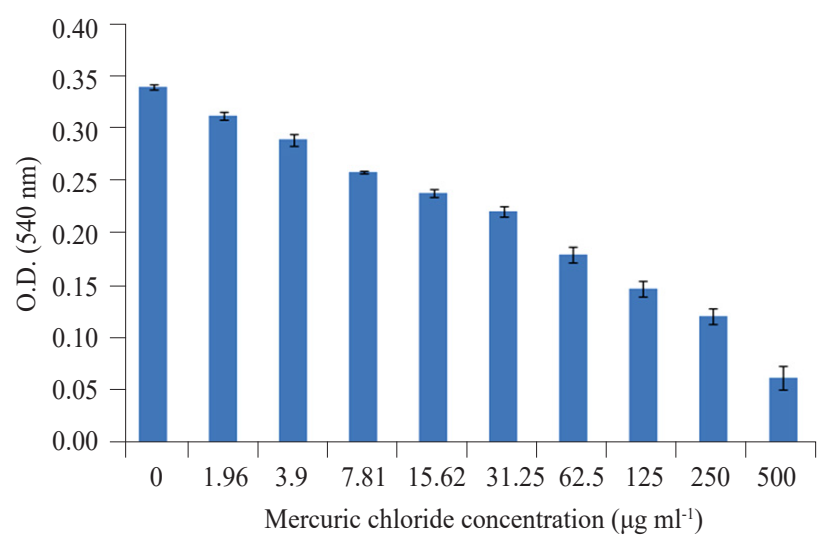

Fig. 7. Cytotoxicity assay; SSK cells incubated with mercuric chloride at increasing concentration levels (1.96 to $500 \mu \mathrm{g} \mathrm{ml}^{-1}$ ) exhibited a decrease in neutral red uptake

which has been named as SSK cell line. Till date, the SSK cells have been successfully passaged for over 62 passages. The optimum growth temperature of SSK cells was determined to be $28^{\circ} \mathrm{C}$. This finding is in conformity with cell lines developed from freshwater fishes in several tropical countries (Ku et al., 2010; Chaudhary et al., 2013, 2014; Sood et al., 2015; Swaminathan et al., 2016;). Similarly, L-15 medium containing 20\% FBS was found as optimum for the growth of SSK cells. Importantly, medium containing 10\% FBS was also found to support moderate growth in the cells and this can be used under routine conditions for maintenance of this cell line. These findings are in accordance with previous reports of several fish cell lines (Sood et al., 2015; Swaminathan et al., 2016;). Moreover, after 4 months storage in $\mathrm{LN}_{2}$, the SSK cells retained good viability $(>80 \%)$. Monolayer was formed within 6 days after revival and importantly, without any morphological alterations, in accordance with previous studies (Ku et al., 2010; Abdul Majeed et al., 2013, 2014; Swaminathan et al., 2016).

Plating efficiency is an important test to measure colonies developing from single cells. The test is generally employed to know the nutritional requirements of cells, test different lots of sera and measure the effects of exogenous growth factors. In case of SSK cell line, though the plating efficiency was low but it was found to improve when more cells was seeded. The low plating efficiency, as reported with SSK cell line, has been reported earlier by various workers (Ku et al., 2010; Sood et al., 2015) but other researchers reported high plating efficiency for $C$. striatus cell lines (Abdul Majeed et al., 2013, 2014).

The chromosomal counting of metaphase spreads reported a diploid chromosome number of 40 in SSK cells and in accordance with that reported in literature for this species (Kumar et al., 2013; Abdul Majeed et al., 2013, 2014; Sood et al., 2015). The variation in chromosome number of SSK cells could possibly be due to additions or loss of chromosomes from neighbouring cells during preparation of chromosome (Swaminathan et al., 2010). It has been suggested by various workers that mitochondrial genes viz. 18S rRNA, 16S rRNA, 12S rRNA and COI can be used for identifying the species of origin of cell lines (Cooper et al., 2007; Cheng et al., 2010). COI gene sequence has been used to identify species including fish (Hebert et al., 2003; Ward et al., 2005). The alignment of sequencing data of COI gene from SSK cells, C. striatus muscle and available sequences in NCBI GenBank confirmed the origin of SSK cell is $C$. striatus.

The transfection efficiency of SSK cells was high in this study. This suggests that heterologous promoter can be used for foreign gene expression in this cell line and useful in conducting studies on functional genomics, as reported previously with many fish cell lines (Qin et al., 2006; Wang et al., 2010; Sood et al., 2015). The immunological markers of cytoskeleton have been used to differentiate the two cell types i.e. fibroblastic and epithelial in fish cell lines (Chaudhary et al., 2014). The lineage of SSK cells, as determined by reactivity with antibodies to fibroblastic and epithelial markers, revealed that the cells of the SSK cell line are of epithelial type.

NR uptake assay is commonly used for cytotoxicity assays (Repetto and Sanz, 1993) and in the present study, the SSK cell's lysosomal integrity was affected following incubation with mercuric chloride and it was confirmed by decrease in NR uptake when the concentration of mercuric chloride increased. The results suggest that SSK cell line can be employed for preliminary screening of different compounds for their cytotoxic effects.

In conclusion, SSK cell line developed from kidney of C. striatus appears to be suitable for short-term cytotoxicity studies as well as for expression of recombinant proteins. The cell line will be useful for investigation of disease outbreaks in snakeheads, suspected to be of viral etiology.

\section{Acknowledgements}

The authors are thankful to the Director, ICAR-National Bureau of Fish Genetic Resources, Lucknow for the guidance and support.

\section{References}

Abdul Majeed, S., Nambi, K. S. N., Taju, G. and Sahul Hameed, A. S. 2013. Development, characterisation and application of a new fibroblastic-like cell line from kidney of a freshwater air breathing fish Channa striatus (Bloch, 1793). Acta Trop., 127(1): 25-32.

Abdul Majeed, S., Nambi, K. S. N., Taju, G., Sarath Babu, V., Farook, M. A. and Sahul Hameed, A. S. 2014. Development and characterisation of a new gill cell line from air breathing fish Channa striatus (Bloch, 1793) and its application in toxicology: 
direct comparison to the acute fish toxicity. Chemosphere, 96: 89-98.

Buonocore, F., Randelli, E., Lorenzen, N., Einer-Jensen, K. and Scapigliati, G. 2011. Analysis of the expression and modulation of selected immune-related gene transcripts in the DLEC cell line from European sea bass (Dicentrarchus labrax L.). J. Aquac. Res. Dev., 2: 105. DOI:10.4172/2155-9546. 1000105

Chaudhary, D. K., Sood, N., Rathore, G., Pradhan, P. K., Punia, P., Agarwal, N. K. and Jena, J. K. 2014. Establishment and characterisation of macrophage cell line from thymus of Catla catla (Hamilton, 1822). Aquac. Res., 45: 299-311.

Chaudhary, D. K., Sood, N., Swaminathan, T. R., Rathore, G., Pradhan, P. K., Agarwal, N. K. and Jena, J. K. 2013. Establishment and characterisation of an epithelial cell line from thymus of Catla catla (Hamilton, 1822). Gene, 512: 546-553.

Cheng, T. C., Lai Y. S., Lin, I. Y., Wu, C. P., Chang, S. L., Chen, T. I. and $\mathrm{Su}, \mathrm{M} . \mathrm{S}$. 2010. Establishment, characterisation, virus susceptibility and transfection of cell lines from cobia, Rachycentron canadum (L.), brain and fin. J. Fish Dis., 33: 161-169.

Cooper, J. K., Sykes, G., King, S., Cottrill, K., Ivanova, N. V., Hanner, R. and Ikonomi, P. 2007. Species identification in cell culture: a two-pronged molecular approach. In Vitro Cell. Dev. Biol. Anim., 43(10): 344-351.

Courtenay, W. R. Jr. and Williams, J. D. 2004. Snakeheads (Pisces, Channidae)- a biological synopsis and risk assessment. U. S. Geological Survey Circular, 1251 vi+143 pp.

Frerichs, G. N., Morgean, D., Hart, D., Sherrow, C., Roberts, R. J. and Onions, D. E. 1991. Spontaneously productive C-type retrovirus infection of fish cell line. J. Gen. Virol., 72: 2537-2539.

Freshney, R. I. 2005. Culture of animal cells: a manual of basic technique. Wiley-Liss, Hoboken, NJ, USA.

Grunow, B., Noglick, S., Kruse, C. and Gebert, M. 2011. Isolation of cells from Atlantic sturgeon Acipenser oxyrinchus oxyrinchus and optimisation of culture conditions. Aquat. Biol., 14: 67-75.

Hebert, P. D., Cywinska, A., Ball, S. L. and deWaard, J. R. 2003. Biological identifications through DNA barcodes. Proc. Biol. Sci., 270: 313-321.

Hossain, M. K., Latifa, G. A. and Rahman, M. M. 2008. Observations on induced breeding of snakehead murrel, Channa striatus (Bloch, 1793). Int. J. Sustain. Crop Prod., 3: 65-68.

Ku, C. C., Lu, C. H. and Wang, C. S. 2010. Establishment and characterisation of a fibroblast cell line derived from the dorsal fin of red sea bream, Pagrus major (Temminck and Schlegel). J. Fish Dis., 33(3): 187-196.
Kumar, R., Kushwaha, B., Nagpure, N. S., Behera, B. K. and Lakra, W. S. 2013. Karyological and molecular diversity in three freshwater species of the genus Channa (Teleostei, Perciformes) from India. Caryologia, 66(2): 109-119.

Lakra, W. S., Swaminathan, T. R. and Joy, K. P. 2011. Development, characterisation, conservation and storage of fish cell lines: a review. Fish Physiol. Biochem., 37(1): 1-20.

NBFGR 2011. Proceedings of the National consultation on species prioritisation for Ex situ conservation and freshwater aquaculture, 17-18 September 2011. National Bureau of Fish Genetic Resources, Lucknow.

Qin, Q. W., Wu, T. H., Jia, T. L., Hegde, A. and Zhang, R. Q. 2006. Development and characterisation of a new tropical marine fish cell line from grouper, Epinephelus coioides susceptible to iridovirus and nodavirus. J. Virol. Methods, 131: 58-64.

Repetto, G., Peso, A. D. and Zurita, J. L. 2008. Neutral red uptake assay for the estimation of cell viability/cytotoxicity. Nat. Protoc., 3: $1125-1131$

Repetto, G. and Sanz, P. 1993. Neutral red uptake, cellular growth and lysosomal function: in vitro effects of 24 metals. Altern. Lab. Anim., 21: 501-507.

Samantaray, K. and Mohanty, S. S. 1997. Interactions of dietary levels of protein and energy on fingerling snakehead, Channa striata. Aquaculture, 156: 241-249.

Sood, N., Chaudhary, D. K., Pradhan, P. K., Verma, D. K., Swaminathan, T. R., Kushwaha, B., Punia, P. and Jena, J. K. 2015. Establishment and characterisation of a continuous cell line from thymus of striped snakehead, Channa striatus (Bloch 1793). In Vitro Cell. Dev. Biol. Anim., 51(8): 787-796.

Swaminathan, T. R., Basheer, V. S., Gopalakrishnan, A., Sood, N. and Pradhan, P. K. 2016. A new epithelial cell line, HBF from caudal fin of endangered yellow catfish, Horabagrus brachysoma (Gunther, 1864). Cytotechnology, 68(3): 515-523.

Swaminathan, T. R., Lakra, W. S., Gopalakrishnan, A., Basheer, V. S., Kushwaha, B. and Sajeela, K. 2010. Development and characterisation of a new epithelial cell line PSF from caudal fin of Green chromide, Etroplus suratensis (Bloch, 1790). In Vitro Cell. Dev. Biol. Anim., 46: 647-656.

Talwar, P. K. and Jhingran, A. G. 1992. Inland fishes of India and adjacent countries. A. A. Balkema, Rotterdam, Two volumes.

Wang, N., Wang, X. L., Sha, Z. X., Tian, Y. S. and Chen, S. L. 2010 Establishment, characterisation and virus susceptibility of a kidney-derived cell line from southern flounder, Paralichthys lethostigma Jordan and Gilbert. J. Fish Dis., 34: 81-85.

Ward, R. D., Zemlak, T. S., Innes, B. H., Last, P. R. and Hebert, P. D. N 2005. DNA barcoding Australia's fish species. Philos. Trans. R. Soc. Lond. B Biol. Sci., 360: 1847-1857. 